\title{
PATRIMÔNIO E MATRIMÔNIO III: ARQUEOLOGIA E REINVENÇÃO DO SABER MATRIMONIAL
}

\author{
PATRIMONY AND MATRIMONIES III: ARCHEOLOGY AND \\ REINVENTION OF MATRIMONIAL KNOWLEDGE
}

Ria LEMAIRE*

\begin{abstract}
Resumo: Desde os anos setenta do século passado, os estudos de mulher e de gênero trouxeram para o campo da historiografia ocidental, além das inúmeras provas das contribuições das mulheres para a cultura obliteradas ou distorcidas pela historiografia oficial, uma visão bem completa das estratégias de exclusão, apropriação, distorção e perseguição desse matrimônio, com o objetivo de perpetuar e justificar a visão do patrimônio cultural como superior, único e (quase) exclusivamente masculino. Repensar as funções e os funcionamentos altamente politizados que tiveram nos séculos XIX e XX as historias das literaturas nacionais e os seus cânones a partir do conceito de matrimônio abre o caminho para uma nova historiografia da cultura ocidental. Resgatar a imensa riqueza dos matrimônios locais e regionais da Europa medieval, bem como detectar as suas raízes, sua continuidade e permanência ao longo dos séculos, permitirão re-descobrir o outro Mundo, o outro projeto histórico que mulheres e seus aliados masculinos instauraram no mundo indo-europeu e continuam defendendo até hoje contra um patriarcado violento e hegemônico.
\end{abstract}

Palavras-chave: Matrimônios. Patrimônio. Historiografia. Colonização. Dualismo.

Abstract: Since the seventies of the twentieth century, women studies and gender-studies have been introducing in the field of western historiography inumerous examples and scientific evidence of women's fundamental contribution to the history of western culture. They also have brought a fundamental insight into the strategies of exclusion, appropriation, distortion and persecution of women's matrimony, for the purpose of perpetuating a vision of western culture as a unique, superior and exclusively male patrimony. Reconsidering and questioning from the perspective of matrimony, the highly politicized functions of literary historiography and its canons in the 19th and 20th century open a new vision and new ways of making historiography, history and canons. Recuperation of the immense treasure of local and regional matrimonies of medieval Europe - discovering its archaic roots, continuity and permanency until nowadays -, creates the perspective of another World, where women and men have been defending another historical project against the violence and hegemony of patriarchy.

Key-words: Matrimonies. Patrimony. Historiography. Colonization. Dualism.

\footnotetext{
* Doutorado em Literatura comparada em línguas românicas medievais. Professora emérita da Université de Poitiers, França. E-mail: rialemaire@ hotmail.com. ORCID iD: https://orcid.org/0000-0003-3215-7830
} 
Nous avons appelé notre cage l'espace, Et ses barreaux déjà ne nous contiennent plus. ${ }^{l}$

Louis Aragon

\section{Introdução}

Este texto integra o painel central de um tríptico, intitulado Patrimônio e Matrimônio, e sintetiza, a partir de dois eventos recentes no campo da manuscritura medieval, os princípios de uma revisão radical da historiografia convencional das literaturas medievais europeias. Comecei a compor e redigir os dois painéis laterais paralelamente, logo depois do Caminho de Santiago, que percorri nos meses de maio e junho de 2017. Na verdade, foi o Caminho de Fisterra, que vai até ao Cabo de Fisterra, a $100 \mathrm{~km}$ a oeste de Santiago de Compostella, cabo que era considerado na Idade Média o fim do mundo. A minha caminhada foi uma busca de rastros e reminiscências do culto da Deusa-Mãe Negra, a virgem dos-cem-mil-nomes.

Imagem 1 - La Morenita: a virgem negra do Mosteiro de Montserrat (Espanha)

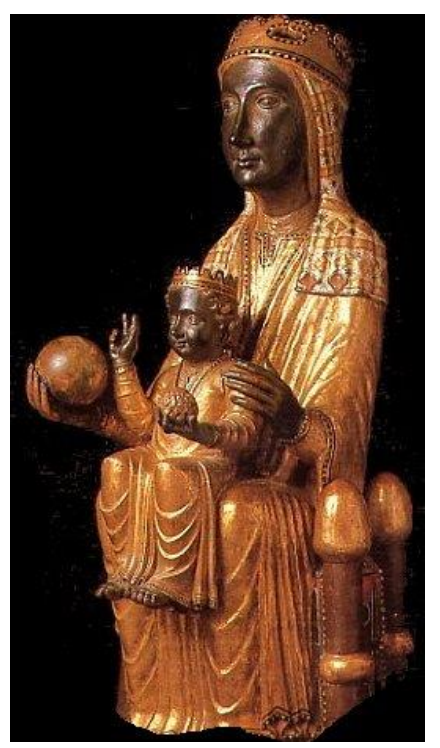

Fonte: Fundação Marypages ${ }^{2}$

Foi ela a padroeira do antiquíssimo caminho original de Fisterra, o das virgenes, sacerdotisas dos santuários da Deusa-Mãe-Terra, um culto anterior à devoção jacobeia, como

\footnotetext{
1 "Chamávamos de espaço a nossa gaiola / E as suas grades já não nos contém mais." (tradução minha).

${ }^{2}$ Disponível em : <https://www.marypages.com/nossa-senhora-de-montserrat-pt.html>. Acesso em: 16/12/2020.
} 
confirma, em 2017, o texto do projeto de instalação da Via Mariana, um novo Caminho de Santiago, de Braga a Muxia na Galiza, publicado em de 25 de junho de 2018:

O fio condutor son as tradicionais Romarías ... que conducen aos santuarios de devoción Mariana, culto anterior à devoção xacobea, e que remite moitas veces a outros cultos de maior antigüidade, de carácter máxico e matriarcal. (VOZ DE GALICIA, 2018).

Foram dois meses de caminhada de grutas a pedras, fontes, capelas e antiquíssimos mosteiros dúplices onde viviam monjas e monges debaixo do mesmo teto, geralmente sob a direção e orientação espiritual de uma mulher, abadessa-sacerdotisa. Porém, a minha caminhada não foi só a do resgate do culto da Deusa-Mãe-Terra, deusa da vida, fertilidade e fecundidade, padroeira do Caminho antigo. Foi também a de uma "arqueologia do saber" (FOUCAULT, 1969), da historiografia oficial do Caminho posterior - o de Santiago -, consignada em uma narrativa-mito (WHITE, 1973) que inventaram, a partir de 843, a Igreja católica e os seus aliados políticos, a elite dos guerreiros da Reconquista. Uma casta políticoreligiosa composta de duas classes sociais - a dos pregadores/rezadores e a dos guerreiros/ predadores -, que se apropriou do caminho ancestral, da fé e do imaginário dos seus peregrinos e peregrinas, com o objetivo de transformar o antigo matrimônio (no sentido original do termo) ${ }^{3}$ em patrimônio, atribuindo-lhe a um protagonista masculino, o apóstolo Santiago, padroeiro dos guerreiros e da Reconquista da Península Ibérica (507-1429).

E, mais especificamente, quis estudar o papel que desempenhou nesse processo de apropriação um dos grandes monumentos da literatura ibérica medieval, o Cancioneiro das 412 Cantigas de Santa Maria, tradicionalmente atribuídas ao rei D. Afonso X, o Sábio, rei de Galiza, Leon e Castela (1252-1284). Muitas dessas cantigas são, na verdade, contrafacta de um gênero antiquíssimo, o das cantigas de romaria/de santuário, cantigas cantadas e bailadas pelas mulheres que contavam as curas milagrosas e outros milagres de virgenes negras e brancas, descendentes longínquas da Deusa-Mãe-Terra Negra. Coligidas nos seus respetivos santuários ao longo do Caminho, essas cantigas foram levadas para os scriptoria do rei Afonso e transformadas em cânticos religiosos, dedicados à única e verdadeira Virgem reconhecida pela Igreja católica, a saber, Maria, mãe branca e imaculada do Cristo.

\footnotetext{
${ }^{3}$ Def. Conjunto dos bens materiais e imateriais, transmitidos, em linha materna, das mães para as filhas e das mulheres para as jovens gerações de mulheres.
} 


\section{A lição dos manuscritos medievais}

Parece que o cosmos inteiro colaborou no momento em que fui construir este painel central do tríptico, que combina os dados e argumentos reunidos nos dois painéis laterais (PeM I e PeM II), com o objetivo de construir uma proposta para uma nova historiografia da literatura medieval. Surgiram dois eventos científicos em torno da manuscritura medieval (a produção, reprodução e transmissão dos manuscritos nos scriptoria dos monastérios e os cortes medievais) que vieram corraborar a visão crítica do novo paradigma científico dos estudos de literatura medieval ${ }^{4}$.

O primeiro evento foi, em finais do ano 2017, o regresso a Vigo, na Galiza, do Pergaminho Vindel, guardado na Morgan Library, em Nova York. Atribuído a um jogral, Martim Codax, o pergaminho é uma folha solta dobrada que data do século XIII e salvaguarda as sete cantigas de amigo paralelísticas "do mar de Vigo", das quais seis constam com a sua melodia. Trata-se do único testemunho/manuscrito medieval da cantiga de amigo e o único que documenta a unidade intrínseca de Letra e Som em que se baseia esse gênero paralelístico que é poesia cantada, bailada, improvisada, dialogada. Esse documento preciosíssimo obriga a uma releitura crítica do primeiro capítulo da história oficial da literatura medieval portuguesa, que só se baseia, até hoje, na existência de dois manuscritos renascentistas italianos do século XVI. Esses dois manuscritos já pertencem a uma era cultural diferente. Só salvaguardam os textos a Letra - das cem cantigas paralelísticas conservadas, ao atribuírem todas elas, sem exceção, a poetas masculinos, escritores/autores no sentido renascentista da palavra. São os eruditos humanistas do Renascimento que inventaram o fenômeno e o conceito de autor/proprietário do texto individual como componente do processo da elaboração da doutrina humanista de homo

\footnotetext{
${ }^{4}$ Produto do grande debate pós-moderno internacional sobre o scriptocentrismo das ciências humanas, esse novo paradigma foi introduzido, desde 1980, no campo dos estudos medievais em línguas românicas por Paul Zumthor (1980), sendo também esse paradigma crítico que fornece os pressupostos para questionar, ainda, a representação do lugar da voz das mulheres na história oficial da literatura medieval. Sabemos hoje que o paradigma convencional dos estudos e do ensino de literatura medieval fundamenta-se em pressupostos que são, na verdade, preconceitos renascentistas. O novo paradigma traz a consciência de que textos medievais não são textos escritos no sentido moderno da palavra, mas registros de vozes humanas que os cantavam, declamavam ou ditavam, são vozes transcritas e, em seguida, copiadas por scriptores que eram escribas profissionais da escrita. Quer dizer: nem a realidade moderna nem a noção atual de escritor/autor existiam na Idade Média! Essas noções podem ter em um manuscrito medieval oito significações diferentes, mas nenhuma delas com o sentido moderno da palavra. E sabemos que as inúmeras variantes que apresentam os diversos manuscritos conservados de um texto medieval não são "erros de copista" a serem corrigidos, mas - e todas em um pé de igualdade - são testemunhas da vida movediça do texto medieval que era transcrito, copiado, reinventado continuamente e circulava em ambientes ainda profundamente orais. O que a nossa formação acadêmica nos ensinou a admirar como sendo a prática "nobre" dos grandes mestres e eruditos dos estudos medievais, a saber: o estabelecimento do texto único e original em uma edição chamada de edição crítica, acompanhada da biografia (mais ou menos inventada) de seu autorescritor, constitui, na verdade, uma distorção gravíssima do texto e da realidade medievais.
} 
sapiens. Depois de cinquenta anos de debates pós-modernos sobre andro, nacional e scriptocentrismos nas Ciências Humanas e nas Letras, e com o regresso das cantadoras do Pergaminho $(P V)$ às suas origens, chegou a hora de questionar, mais uma vez, não só a história oficial delas, como também alguns dogmas inabaláveis da disciplina dos estudos medievais.

O segundo evento, ocorrido em janeiro de 2019, deu-se em torno da publicação, em Science Advances (AAAS, 2019), dos resultados de uma pesquisa interdisciplinar e internacional de arqueólogos, antropólogos, cientistas, historiadoras e teólogas sobre a descoberta, no ano 2012, no cemitério do monastério alemão de Dalheim, do corpo de uma monja que lá viveu no século XI e que teve os dentes pincelados de azul. Essa descoberta trouxe um questionamento da base da historiografia convencional do texto medieval, a saber: o seu conceito-chave de homo sapiens, a episteme de que só foram homens-monges, escribas e artistas masculinos os responsáveis pela feitura dos manuscritos medievais e das suas iluminuras. Esse pressuposto tem funcionado, na historiografia acadêmica, como um dogma inquestionável, baseado no fato de que, antes do século XV, escribas raramente assinavam os seus trabalhos. $\mathrm{O}$ anonimato, por absurdo que possa parecer uma prática tão pouco científica, tem levado homo sapiens a ser considerado automaticamente o autor. Apesar do fato de o substantivo escriba ter uma desinência feminina, foi feita a atribuição do produto manuscrito anônimo a um escriba/iluminador masculino, antes de ele começar a servir como fundamento do dogma da autoria masculina (FOUCAULT, 1969).

\section{Sete cantigas "do mar de Vigo"?}

Ondas do mar de Vigo Se vistes meu amigo

E, ay Deus, e ou é?

Em outubro de 2017, mais de cem anos depois de terem sido descobertas em Madrid, em 1914, pelo libreiro Vindel, as sete cantigas paralelísticas "do mar de Vigo" voltaram de Nova Yorque à sua terra de origem. Foram instaladas sob altíssima vigilância, no magnífico Museu do Mar de Vigo, em um espaço meio estéril, inóspito e longe da entrada do museu. Ali, o visitante que se aproximava, ouvia música religiosa medieval, lenta, contemplativa e solene. Além da música "erudita", objetos religiosos e documentos manuscritos ilustravam o "berço" das sete cantigas, a saber, a cultura das elites da época (séc. XIII), apresentada como variante galega de uma "cultura trovadoresca" internacional; cantigas escritas pelo jogral Martim 
Codax, "promovidas a", e ele sendo apresentado como trovador. Foi esse o teor dos comunicados enviados à imprensa e mídia galegas, como o das apresentações durante as visitas guiadas e o da maravilhosa edição de luxo do Pergaminho, publicada pela Editora Moleiro, de Barcelona. Um congresso internacional em torno do manuscrito também foi organizado, logo em novembro, pelos colegas da Universidade de Vigo.

Os dezoito capítulos das atas do congresso (GUERRA, FREIXEDO, 2018) trazem um magnífico tesouro de conhecimentos que oferece uma visão bem completa da gênese e evolução de 104 anos de debates, controvérsias e contradições científicas provocadas pela descoberta do Pergaminho em 1914. De um lado, há as contribuições dos pesquisadores que corraboram a visão oficial radicalmente scriptocêntrica, androcêntrica, renascentista e positivista que nenhum eco dos debates pós-modernistas dos últimos cinquenta anos conseguiu abalar. Repete-se, apesar de quarenta anos de pesquisas e publicações fundamentadas no novo paradigma de estudos medievais, estabelecido por Paul Zumthor, o grande mito de uma cultura escrita trovadoresca de poetas geniais, individuais que "escreveram" essas cantigas "do mar de Vigo". De diferente perspectiva, há as contribuições da outra vertente/escola de pesquisadores que pressupõem a existência de uma cultura pré-trovadoresca oral, simples e "primitiva", "genuína", de canções cantadas por mulheres, das quais trovadores e jograis-escritores teriam aproveitado, ou imitado, para uma elaboração escrita, culta e artística, transformando-as - como escreveu Roman Jakobson, em 1976, em uma carta a Haroldo de Campos - em “joias da lírica europeia".

A incompatibilidade radical e a dicotômica das duas escolas e suas hipóteses básicas sobre as origens dessas canções de mulher dialogadas - cultura oral, pré-trovadoresca, autóctone versus cultura trovadoresca culta e internacional - não impedem um consenso radical e categórico sobre o outro aspecto das origens: as duas escolas mantêm, sem provas científicas, a tese da elaboração artística e autoria escrita masculinas.

Porém, pelos interstícios dos dezoito capítulos das atas do congresso, insinuam-se, confome o pressuposto-dogma inquestionável e sacrossanto da autoria de homo sapiens, diversas propostas, baseadas em pesquisas recentes e/ou ainda em curso, que anunciam uma futura reviravolta, ao acentuarem a "matriz oral e regional" de uma tradição oral feminina. A esse tema, vem juntar-se a descoberta, pela análise paleográfica e codicológica, do caráter híbrido da própria "escrita" do pergaminho. Como era o caso da maior escriba medieval alemã, a monja Diemut (século XII), cujos manuscritos mostram que ela tinha cinco monjascolaboradoras; houve para a folha única do Manuscrito Vindel inúmeros colaboradores. Os 
próprios textos - sete cantigas - foram transcritos por dois - ou duas? - escribas diferentes e em períodos diferentes; dois escribas caligrafaram os iniciais, dois copistas diferentes criaram as partituras, e houve, ainda, outra mão que inscreveu, mais tarde, o nome de Martim Codax no pergaminho. A inscrição desse nome, na época do Renascimento, três séculos mais tarde, levou automaticamente a atribuição da Letra dos sete textos transcritos ao jogral Martim Codax e ia servir, na historiografia nacional portuguesa do século XX, depois da descoberta do Pergaminho Vindel, como prova da sua Autoria de Letra e Som.

Um estudo musicológico do manuscrito, muito fino, complexo e pertinente, demonstra a permanência e preponderância da prática musical do gênero do canto bailado da tradição oral originária nas melodias das seis cantigas musicadas. A conclusão do leitor só pode ser, a meu ver, de que, em relação ao som das cantigas, as verdadeiras compositoras foram as mulheres que as cantavam, bailando nas romarias e em muitas outras ocasiões. Ao avaliar as poucas correções/inovações "eruditas" como sendo secundárias, o autor do artigo coloca a questão central para as futuras pesquisas: "Quais destes traços remontarão à tradição feminil presumivelmente imitada e quais deles corresponderão ao investimento artístico dos jograis?" (FERREIRA: 2018, p.252). Ora, análises críticas desse tipo de "investimentos" obrigam a acrescentar outra pergunta, mais importante ainda: Como provar que esses supostos "aperfeiçoamentos" melhoraram os textos? ${ }^{5}$

Diante da constatação explícita de que não existem documentos que mostram e comprovam esse investimento artístico-culto, Ferreira (2018, p.252) conclui que "a resposta terá de ser especulativa", construindo sua especulação em uma linda tríade retórica em torno do verbo imaginar. Ela retoma o velho dogma/tabu do discurso oficial, bem como revela e ilustra o delírio ficcional que provoca a voz da mulher, desde o humanismo renascentista até hoje, no século XXI, no imaginário dos eruditos: "Nada impede que se imagine uma arcaica tradição de cantigas de mulher. Nada impede que se imaginem os jograis a transformar tal tradição. Pode mesmo imaginar-se que os jograis lograram expandir o âmbito melódico" (FERREIRA, 2018, p. 239).

Será que a linda tríade consiste em sarcasmo retórico, em um ambiente acadêmico ainda tão convencional em que a simples hipótese de uma voz de mulher-autora seja considerada, de

\footnotetext{
${ }^{5}$ Em muitos casos, na tradição europeia, a transcrição de textos orais pelos pesquisadores dos séculos XIX e XX causou mutilações graves da sua mensagem poética, como será o caso também dos folhetos dos poetas da literatura de cordel brasileira, publicados pela editora Luzeiro, de São Paulo, depois de terem sido "corrigidos", reescritos por um erudito professor da USP, que os "aperfeiçoou", e, nesse processo, alterou e até destruiu ritmos, rimas e outros elementos poéticos maravilhosos do texto oral.
} 
antemão, a-científica e provoque - como aconteceu do novo durante o congresso de Vigo ataques arrogantes e agressivos da parte de pesquisadores masculinos contra pesquisadoras que propõem, confrontadas a tantas contradições aberrantes, pesquisar a hipótese da voz da mulher? Ou será que o tabu ainda é tão poderoso e inquestionável que nem o princípio mais elementar de toda e qualquer pesquisa científica tenha valor perante ele? Refiro-me aqui ao princípio de que, quando a pesquisa é confrontada acerca da ausência de documento comprovante, ela tem de começar imperativamente pela hipótese mais simples e objetiva! Nesse caso, a voz de cantadora de cantiga de amigo paralelística improvisada, dialogada, não seria, por acaso, voz de mulher, poetisa-cantadora-improvisadora? Quer dizer, de mulheres que inventavam e reinventavam cantigas que a crítica literária invariavelmente - e apesar dos supostos e incansavelmente proclamados "aperfeiçoamentos cultos" - carateriza como "simples, ingênuas, espontâneas e naturais"?

No congresso, foi proposto outro fator preocupante para a historiografia oficial nacional e nacionalista das sete cantigas: o manuscrito não é galego-português! Como os outros manuscritos de poesia lírica do século XIII, como o Cancioneiro da Ajuda das cantigas de amor anônimas medievais e As Cantigas de Santa Maria, do rei Afonso, o manuscrito provém dos scriptoria da corte de D. Afonso X, o Sábio, rei de Galiza, Leon e Castela, sendo os três manuscritos de origem galego-leonesa-castelã. Consequentemente, impõe-se - até prova do contrário - a exigência de ler e intepretá-los dentro do contexto cultural e literário que foi o das Cantigas de Santa Maria (CSM), a saber, o contexto político-religioso e cultural dos santuáriuos do Caminho de Santiago. Nesse sentido, o regresso do Pergaminho Vindel foi também uma oportunidade para reforçar a hipótese da origem não portuguesa, não nacional, mas local, regional e galego-castelã, com base nos trabalhos do historiador Antônio Resende de Oliveira que, já em 1994, publicou um "Cancioneiro de jograis galegos”, em que constam 33 poetas de condição jogralesca oriundos da Galiza, entre os quais estão Martim Codax (RESENDE, 1994).

A tese de Resende foi retomada por Antônio Souto Cabo que, ao recontextualizar as sete cantigas, descobriu que dez desses 33 jograis do Sul da Galiza, juntamente com Martim Codax, estão presentes nos dois cancioneiros italianos do séc. XVI e que aí figuram exclusivamente com cantigas do gênero das cantigas de amigo paralelísticas de santuário. Quer dizer: com nomes de jograis (Johan de Cangas, Martin de Giinzo, Johan de Requeixo), especialistas de cantigas que estão ligadas ao santuário da romaria da aldeia ou vila onde nasceram! Fato surpreendente que o pesquisador utiliza para elaborar a proposta de estudar as sete cantigas do Pergaminho Vindel dentro do contexto cultural e político-religioso galego-leonês-castelão, que 
foi o das Cantigas de Santa Maria. Elas poderiam e, muito provavelmente, deveriam ser lidas não como cantigas “do mar de Vigo", mas como cantigas “do santuário de Vigo". As cantigas paralelísticas atribuídas aos dez jograis galegos, dos quais os cancioneiros salvaguardam apenas cantigas de amigo paralelísticas, teriam sido componentes integrantes de um projeto de recolha das cantigas lírico-religiosas dos santuários dos Caminhos de Santiago, paralelo ao projeto do cancioneiro lírico-narrativo desses santuários nas Cantigas de SantaMaria.

\section{O contexto político-religioso do Pergaminho Vindel: a nova hipótese}

A Igreja católica tem uma história secular de perseguição às cantigas de mulher, que falavam de "amores", do corpo, de desejo e prazer sexual e erótico, a partir de uma concepção positiva, sagrada da sexualidade e do amor, radicalmente diferentes da doutrina negativa que a Igreja estava propagando nos textos dos concílios medievais, qualificando-as como "turpias e obscenas", como pecado. Uma das estratégias para erradicar da vida e do imaginário dos fiéis essas práticas odiadas, foi a dos contrafacta, que consistia na apropriação, imitação e transformação das cantigas de "amores" em cantares e cânticos de Amor, a saber: amor espiritual ao divino/à Virgem Maria. Essas reescrituras eram divulgadas em seguida, em grande escala, graças ao aproveitamento da tecnologia da escrita e mais tarde da imprensa. No estudo intitulado El villancico (ROMERALO, 1969), constam diversos exemplos desse processo de apropriação e adaptação à "via do divino". Ao manterem o som e o ritmo da canção, poetas introduzem pequenas modificações, como no seguinte refrão de uma canção de mulher um pouco maliciosa e que o poeta culto Fray Iñigo de Mendoza (1425-1507), em seus Coplas de Vita Christi, copiou e alterou para utilizá-lo como refrão de um canto religioso, ao divino, dedicado ao menino Jesus:

$\begin{array}{ll}\text { Eres niña e has amor, } & \text { Eres niño y has amor } \\ \text { que harás quando maior? } & \text { que harás quando maior? }\end{array}$

Nos Villancicos de Navidad (1603), o poeta Lope de Sousa, para a sua "vuelta ao divino" copia até a estrutura antiga da canção de mulher - a do diálogo da filha com a mãe - para inventar uma canção religiosa de Natal, sempre fiel ao som e ritmo originais:

Enemiga le soy, madre a aquel caballero yo.

Mal enemiga le soy
Muy amiga le soy madre

A aquel Jesús que nació.

Más que a mi le quiero yo. 
O objetivo desses contrafacta não deixa dúvida: fazer cantar ao povo que vem para a missa de Natal os cantos eróticos ancestrais cujos ritmos poéticos têm embalado a vida de suas comunidades desde sempre; oferecer-lhes essa consolação saudosa e reconforto ilusório nos sofrimentos, guerras, massacres de mulheres, fome e miséria que lhes traz o começo dos tempos ditos "modernos". Dar-lhes aquela sensação sossegadora de que, apesar da nova lição da cantiga, apesar de tudo, tudo ficou na mesma, que nada mudou, para que o povo, mais uma vez iludido, se resigne à nova ordem mais desigual, mais injusta que a elite político-religiosa impunha (VANCE, 1972).

Esta pequena excursão em terras renascentistas, em que já dispomos às vezes, graças à moda renascentista dos grandes "Cancioneiros ibéricos" - tanto das versões e variantes das canções orais tradicionais, quanto das suas reinvenções sob a forma de cantares ao divino -, mostra bem o funcionamento da estratégia do "cantar ao divino". Consiste na recolha do canto lírico feminino oral, nos respetivos santuários, sua transformação em canto religioso e a redação escrita para divulgação do novo texto por meio da sua re-oralização durante as grandes festas religiosas tradicionais, com o objetivo da aprendizagem empática, meio inconsciente, ritmada, pela voz e pelo corpo bailando, da nova doutrina.

As 412 Cantigas de Santa Maria (CSM) - cantigas narrativas de curas milagrosas com refrão apologético da Virgem milagreira - oferecem exemplos fascinantes dessa estratégia de "lavagem cerebral". O objetivo era erradicar do imaginário dos peregrinos e romeiros a lembrança das mil virgenes milagreiras, negras e brancas, e substituí-la pela fé na única e verdadeira Virgem Maria, mediante a estratégia de atribuição a Ela só, de todos os milagres conhecidos e cantados. A cantiga 41 das Cantigas de Santa Maria, por exemplo, foi recolhida em um dos santuários ao longo do caminho primitivo de Santiago, em Seixões, perto da cidade de Leon, onde iam em romaria os "sandeus", pessoas com problemas de saúde mental. O CSM contém seis cantigas desse santuário. Os versos em itálicos são os que eram cantados por todos os peregrinos e romeiros:

\author{
Refrão: \\ Virgen Madre de Nóstro Sennor \\ ben póde dar séu siso \\ ao sandeu, pois ao pecador \\ faz aver Paraíso \\ En Seixons fez a Garin cambiador \\ A Virgen Madre de Nostro Sennor \\ que tant'ouve de o tirar sabor \\ A Virgen Madre do Nostro Sennor
}




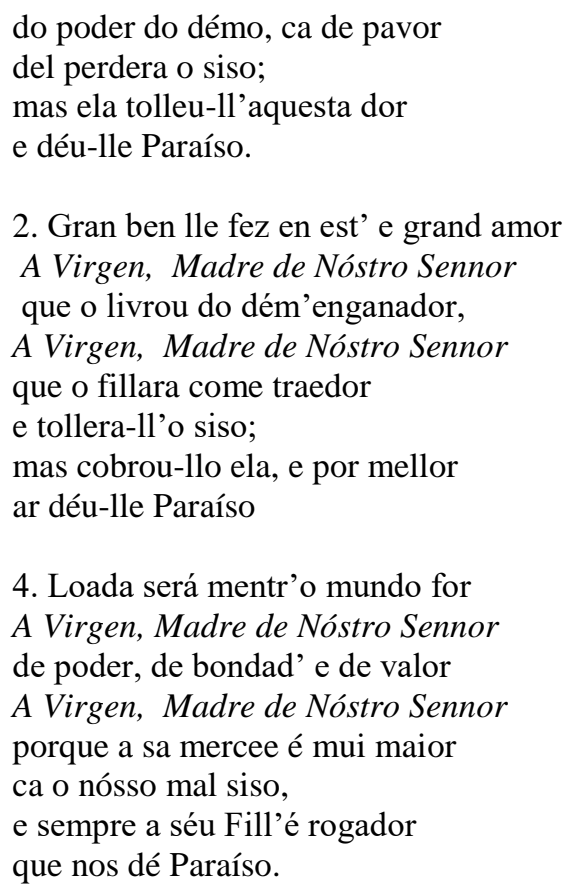

Infelizmente, não existe mais o texto da canção lírico-narrativa original, mas não é difícil para o medievalista reconhecer, debaixo da versão conservada, a estrutura antiga, de origem celta, dessas cantigas bailadas pelas mulheres. Trata-se do ritmo e verso da carole ou rondel, uma sextilha com o esquema das rimas aaabab, acompanhada de um refrão, e com versos do mesmo refrão intercalados - para serem cantados pelos peregrinos - entre os versos das sextilhas. Essa estrutura estrófica permitia lançar ao romeiro um apelo empático duplo: de escuta atenta da parte narrativa, de um lado, e de participação interativa pelos versos do refrão intercalados na parte narrativa e repetidos na parte apologética, de outro lado. Juntamente com os exemplos dos contrafacta dos séculos XV e XVI, a cantiga 41 das CSM permite ter uma visão do que foi, no século XIII, a transição da oralidade para a - tecnologia da - escrita e, no limiar dos tempos modernos, para a imprensa. Em termos de Paul Zumthor (1980), houve uma lenta e progressiva evolução secular da "oralidade primária à oralidade mista, à oralidade segunda", quando já se "escrevem" - ao menos fragmentos de - textos para serem devolvidos ao mundo da oralidade e utilizados, re-oralizados, para dança, canto e declamação.

Reler uma só cantiga da recolha das CSM já permite dar-se conta de que essa suposta evolução que a historiografia oficial representa como um imenso progresso para a humanidade toda, na verdade, se for examinada do ponto de vista do matrimônio da voz da mulher, não o é. Os contrafacta constituirão, a partir da segunda era medieval (1000-1500), uma estratégia da casta político-religiosa do mundo ocidental para a imposição e legitimação do monopólio do patriarcado/patrimônio por meio do silenciamento da voz da mulher. Ao recolher as tradições 
orais que a Igreja não conseguia extirpar, nem com ameaças, nem com penitências e outras penas, ao transcrever, reinventar e propagá-las, ela as repunha "na boca das mulheres" e no seio das comunidades e romarias tradicionais.

De fato, a história oficial da literatura - que, até recentemente, propagava que as 412 cantigas do CSM foram "escritas" por um grande rei-herói erudito que recebeu o título honorífico de Afonso X o Sábio - consiste apenas em uma narrativa ficcional que engrandece e enaltece exagerada e injustamente o gênio masculino. Ao mutilar a verdade histórica, essa ficção tornou invisível o matrimônio antigo e ocultou a luta político-religiosa que foi a sua principal motivação, a saber: manipular o imaginário religioso dos peregrinos para que se esquecessem das virgenes negras e brancas do Caminho. Seguindo o mesmo esquema, aprendemos no primeiro capítulo da História da Literatura Medieval Portuguesa que as cantigas de amigo paralelísticas do santuário de Vigo são cantigas do "mar de Vigo", "escritas" por homens trovadores que, com uma intuição genial da alma feminina, as puseram na boca das mulheres! Assim, são desterritorializadas para serem nacionais, tese reforçada pela ciência da linguística portuguesa que, em finais do século XIX, elabora sistematicamente a noção galegoportuguês e os estudos de língua galego-portuguesa ${ }^{7}$.

\section{A monja dos dentes azuis}

Durante as escavações do mosteiro de mulheres de Dalheim (IX-XIV séc.), no Sul da Alemanha, os arqueólogos exumaram o corpo de uma monja do século XI cujos dentes estão pincelados de pequenas manchas azuis, identificadas como restos de pigmento de lápis lazúli, o pigmento mais caro da época. Importado durante a Idade-Média de uma mina no Afeganistão, esse pigmento era utilizado exclusivamente por artistas-ilustradores altamente especializados e competentes, para as iluminuras dos manuscritos mais luxuosos. Foi constituída logo, em 2012, uma equipe de investigação interdisciplinar que demonstrou que a monja, para a aplicação do precioso pigmento em iluminuras, ao pintar, lambia a ponta do pincel, permanecendo, assim, na sua placa dentária, esses resíduos azuis. Foi identificada uma mulher, artista altamente especializada e competente, produtora de manuscritos iluminados de luxo, cuja presença anônima questionou uma crença comum, a de que só os homens dos monastérios masculinos eram escribas e ilustradores (A.A.A.S., 2019).

\footnotetext{
${ }^{7}$ Como fez Carolina Michaëlis de Vasconcellos (1904) ao emendar sistematicamente o manuscrito de Cancioneiro da Ajuda. Na sua transcrição e edição crítica do manuscrito a semi-vogal - $l l$ - galego-leonesa-castelã do manuscrito- foi substituída sistematicamente pelo -lh-português.
} 
A pesquisa interdisciplinar, de repente, permitiu recolocar no palco uma tradição de pesquisas sobre o papel da mulher na cultura germânica medieval e uma extensa bibliografia sobre o assunto. Desde a época do Romantismo, eruditos alemães, em vez de excluírem a questão da mulher, têm investigado e acentuado nas suas publicações o papel fundamental das mulheres como agentes culturais. Não é por acaso que Carolina Michaëlis de Vasconcellos, formada na tradição científica alemã do século XIX, inseriu na edição crítica das cantigas de amor masculinas, ditas "provençais", do Cancioneiro da Ajuda (1904), dois capítulos magistrais sobre a voz da mulher galega e o seu contexto: a cultura autóctone medieval da Galiza.

Essa riquíssima tradição alemã oitocentista é de difícil acesso. Os estudos estão redigidos em alemão e, diversos deles, impressos com letra gótica. Porém, a bibliografia do artigo publicado em 2019, em Science Advances, traz três estudos ricos e recentes em língua inglêsa que cobrem globalmente as três fases da história regional da qual faz parte a monja dos dentes azuis do século XI, a saber, a dos monastérios femininos do Sul da atual Alemanha, de toda a Idade Média, do século VI até finais do século XV.

Estudos de Felice Lifshitz (2014): do século VI até a Reforma carolíngia

São, no século VI, monges e monjas anglo-saxônicas que vêm cristianizar a Germania do Sul. Vivem em monastérios duplos mistos, sob a autoridade de uma abadessa, na tradição monástica fundada em 470 por Santa Brígida da Irlanda. Geralmente, são as grandes famílias da nobreza alemã que são as fundadoras-construtoras-financiadoras dos novos monastérios a serem dirigidos por mulheres da alta nobreza. Muitas fundadoras eram rainhas, ou mulheres da nobreza, cultas, ricas e poderosas. As monjas missionárias trouxeram para a Germânia os seus scriptoria com a sua tradição de produção, transmissão, estudo e divulgação de textos religiosos, litúrgicos e teológicos. A sua missão central era a cristianização do povo por meio de um intenso trabalho social e missionário que comportava pregação, celebração de missa, administração dos santos sacramentos, educação e ensino, acompanhamento de pobres e doentes, cura pela medicina das plantas e ervas, além de transmissão da sua cultura inteletual, religiosa e teológica.

O estudo de Lifshitz (2014) demonstra que essa cultura cristã, trazida por missionárias e missionários anglo-saxônicos ainda era "thoroughly gender egalitarian", e que as abadessas 
dos conventos mistos duplos tinham uma grande autoridade ${ }^{8}$ e reputação, bem além das fronteiras da sua região. As correspondências e outros documentos da época revelam que existia uma profunda consciência da existência de uma dualidade, a saber, um "mundo das mulheres", autônomo e diferente do "mundo dos homens", cada um com os seus direitos e deveres a serem respeitados reciprocamente. No manuscrito do Salisbury Psalter (séc.X), por exemplo, as monjas ainda substituem sistematicamente as desinências latinas masculinas por flexões femininas, tais como famulum tuum (Seu servidor), corrigido por : famulam tuam (Sua servidora).

Uma análise textual das correspondências, crônicas e outros documentos mostra que o trabalho inteletual/escrito daquelas mulheres espirituais baseava-se em um foco duplo. De um lado, havia o diálogo - altamente abstrato, teórico e erudito sobre assuntos teológicos, doutrinários - que as monjas tinham, em um pé de igualdade, por exemplo, com os monges e monastérios masculinos da ordem beneditina que tentavam impor a sua regra monástica em toda a cristiandade ${ }^{9}$. De outro lado, havia um diálogo interno, muito mais prático e pedagógicodidático, com as mulheres das suas comunidades e das outras comunidades femininas e duplas, que tinha por finalidade discutir e ensinar a doutrina monástica da Ordem e o seu posicionamento em relação às regras impostas pelo Papa de Roma (mediante a ordem beneditina), aplicando e adaptando-as da melhor maneira possível à vida da comunidade. Para o bem e bem-estar de todas e todos, as monjas redigiam e copiavam, nos seus scriptoria, também poesias, cantos, músicas, peças de teatro, textos litúrgicos, manuais medicinais, crônicas, biografias, entre outros textos, para uso exclusivo nas comunidades femininas e mistas.

Em 817 chegou a primeira grande Reforma beneditina da vida monástica, chamada de Reforma Carolíngia, com a imposição, em todo o Império carolíngio, da regra beneditina única para todos os monastérios do Império. A reforma introduz - contra a prática missionária e social da tradição monástica anglo-saxônica, baseada na abertura para a vida local e regional das comunidades de fiéis - os princípios da clausura, da combinação de trabalho manual, inteletual e religioso, o ideal de pobreza e humildade, todos praticados de preferência dentro dos muros

\footnotetext{
${ }^{8}$ Seria interessante introduzir a distinção entre esta auctoritas da primeira fase da cristianização, a autoridade intelectual e espiritual baseada na sabedoria partilhada, e uma segunda significação derivada dela e, mais tarde, sobreposta a ela: auctoritas/ potestas, o poder patriarcal, baseado na vontade de controle de cima e de fora, que começa a se impor desde a renascença carolíngia, capítulo final do estudo de Lifshitz (2014).

${ }^{9}$ A Ordem beneditina foi fundada em 529 na Itália e se propagará progressivamente na Europa ocidental. Sob a proteção do Papa de Roma, ela tentará impor a sua Regra monástica beneditina como única e verdadeira (529817), às despesas das - e contra as - inúmeras ordens e formas de vida religiosa comunitária, locais e regionais.
} 
do próprio monastério. Acaba-se o diálogo em um pé de igualdade, e inicia-se uma luta secular das mulheres-monjas contra as consequências dramáticas que a Reforma vai inflingir no decorrer dos séculos para a autonomia da sua vida monástica, social e misssionária nos monastérios duplos mistos. Porém, o poder de fundadores/financiadores nobres e a autoridade das mulheres-abadessas desses monastérios eram grandes; a Reforma não pode ser aplicada imediatamente com toda a sua rigidez, como mostrará a história das fases seguintes.

Estudos de Alison Beach (2004): Segunda Reforma beneditina (XI) e Apogeu da Idade Média (XII)

A segunda Reforma beneditina, chamada de Reforma de Cluny, pretendeu, pôr fim ao poder que as famílas nobres e reais fundadoras dos monastérios exerciam, ao pôr todos os conventos sob a autoridade direta e exclusiva do Papa de Roma e dos seus representantes, a saber, os abades masculinos dos grandes monastérios beneditinos (BEACH, 2004). Implicitamente, a reforma tentou dar cabo do poder e da autonomia e liderança espiritual das abadessas. Ela proibiu a criação de novos monastérios mistos duplos, prescrevendo a construção de monastérios duplos separados, um monastério masculino e um monastério feminino, situados a uma pequena distância um do outro e sob uma autoridade central, a do abade do convento masculino. Na verdade, a luta contra as abadessas tinha começado bem antes. A transição foi preparada desde o segundo Concílio de Nicéia, em 787, como mostra o capítulo XX das Ordenações estabelecidas pela hierarquia ecclesiástica reunida: "Não se farão mais mosteiros duplos". A luta ia ser longa, a vitória só nos Tempos Modernos. No começo do século XII, já em plena reforma de Cluny, Roberto de Arbrissel fundou na França, em Fontevrault, um monastério duplo misto sob a autoridade de uma abadessa. O monastério tornou-se o maior monastério da cristiandade ocidental a ser dirigido, geral, mas não exclusivamente, no decorrer dos séculos, por uma abadessa, o que vigora até 1789, quando chega a Revolução Francesa que põe fim a todos os monastérios do país.

O século XII, apogeu da Idade Média, trouxe também o apogeu da arte da manuscritura. Magníficos conventos, riqueza, uma manuscritura de luxo. Um exemplo é o monastério alemão - duplo misto, mais tarde duplo separado - de Wessobrun, no Sul da Alemanha. Fundado e codirigido pela família nobre Rott em 753, o monastério torna-se, em 788, o monastério imperial. O seu apogeu ocorre nos finais dos séculos XI e XII, quando os monges reconstrõem (1065) o monastério existente, transformando-o em duplo separado. Em 1100, estará pronto o monastério feminino sob a autoridade do abade. A riquíssima biblioteca do monastério duplo 
separado foi criada pela maior escriba-iluminadora da Idade Média germânica, a monja-reclusa Diemut. Foi ela a fundadora da biblioteca do convento. À sua morte, os monges a enterraram com imensa gratidão, como mostra o epitáfio do túmulo, em que se lê: "Diemut, reclusa de piedosa memória que criou com as suas próprias mãos a Biblioteca do Monastério de São Pedro, faleceu no dia 30 de abril".

Ficaram conservados por sua mão 14 manuscritos, cuja análise paleográfica e codológica permitiu demonstrar que Diemut trabalhava com cinco escribas-colaboradoras. Parece que o impacto feminino nunca enfraqueceu no imenso complexo conventual. Em 2014, ele foi comprado por uma mulher alemã, Martina Gebhardt, que reinstalou o herbarium medieval e, dentro da tradição feminina medieval da medicina dos "simples", das ervas, criou a famosa linha de produtos cosméticos naturais, Naturkosmetik ${ }^{10}$.

Estudos de Cynthia Cyrus (2009): do século XIII até à Reforma dominicana do século XV

Cynthia Cyrus pesquisou durante vinte anos nas bibliotecas do Sul da Alemanha sobre os manuscritos de 450 monastérios de mulheres dos séculos XIII-XV, dos quais 48 mantiveram scriptoria. Ficaram conservados nesse período os nomes de 416 escribas femininas, das quais 316 se identificaram como scriptrix ou soror. (Schreiberin ou Schwester), tais como a monja Gertrudis que, com um suspiro de grande alívio, escreve, no século XIV, no colofone de um manuscrito por ela produzido em alemão medieval: "It is finished, let it be done. The scribe thanks God. Who has written me has the name Gertrude" (CYRUS, 2009, p. 139, tradução minha) ${ }^{11}$.

O estudo desses manuscritos femininos da última fase da Idade Média permitiu a Cyrus (2009) concluir que, durante todo o período medieval, tanto na primeira era medieval nos monastérios duplos mistos (Lifschitz) como na segunda era medieval (Beach) e na fase final da Idade Média, a manuscritura foi, na Alemanha do Sul, uma profissão e arte predominantemente feminina. Cyrus demonstra também que permaneceu vivo durante todos esses séculos - e ao lado da regra monástica masculina de origem beneditina - o ideal de vida monástica missionária da primeira era medieval, que se fundamentava na vida autônoma da comunidade, voltada para e adaptada à vida local/regional. Inspirada pela compaixão com todos os seres vivos e à

\footnotetext{
${ }^{10}$ No século XX, ilustrada pela herborista austríaca Maria Treben (1907-1991), cujo manual, Gesundheit aus der Apotheke Gottes (A saúde vem da farmácia de Deus), foi traduzido para mais de 30 línguas, totalizando a venda, quando faleceu a autora, em mais de 10 milhões de exemplares.

${ }^{11}$ No original: "It is finished, let it be done. The scribe thanks God. Who has written me has the name Gertrude."
} 
responsabilidade social, as monjas dedicavam-se à educação das mulheres e a uma espiritualidade baseada no amor incondicional e ao acesso direto ao divino. A autora salienta a luta secular das monjas pela independência e liberdade de escolha, ao descrever uma tradição intelectual voltada - não como prescreve a regra beneditina que se pretende universal e única para a vida dentro do monastério, mas, pelo contrário - para a prática da vida comunitária e social, local, regional e plural, adaptada a cada situação concreta e específica do momento. Uma tradição que não é o produto de uma ciência/doutrina abstrata, formal, teórica, imposta de cima, de fora e de longe - essa ciência sem consciência imposta de cima, de fora e de longe. Ela é consciência, sabedoria, construída de dentro da comunidade e com a experiência concreta da sua vida, uma ciência-consciência que só hoje em dia uma - ainda - vanguarda de pensadores começa a redescobrir.

Estudos de Stefanie Neidhardt (2017): a Reforma dominicana no limiar dos Tempos Modernos

Essa exigência de autonomia, abertura e pluralidade do mundo monástico feminino e a sua resistência ao poder e controle impostos pelos monastérios masculinos são o tema central da tese de doutoramento em teologia de Stefanie Monica Neidhardt (2017), que estudou as correspondências e crônicas de três grandes monastérios de mulheres no Sul da Alemanha em relação a uma terceira grande Reforma, a Observanz dominicana do século XV, ocorrida já no limiar do que nos aprendemos a chamar de "Tempos Modernos". As reformas que a hierarquia da Ordem quis impôr mostram a vontade de destruir radicalmente o mundo espiritual das mulheres-monjas, base do seu matrimônio secular. As correspondências e crônicas escritas pelas mulheres são testemunhos da sua resistência e busca de estratégias de salvaguarda da Autonomie im Gehorsam, como diz o título da tese: a autonomia preservada, dentro dos limites impostos pela necessidade de obediência às ordens da hierarquia masculina, apresentadas como vontade do Papa, representante e porta-voz no mundo terrestre da vontade de Deus. Eis as reformas principais:

- Substituição da prática da espiritualidade feminina, mística e individual pela religiosidade comunitária, mediante a imposição das práticas do canto e da oração coral de todas as monjas juntas, em horas fixas, e da leitura edificante durante as refeições. Proibição das experiências místicas individuais; os livros de devoções, rezas e cantos que acompanham a experiência mística altamente individual da comunicação direta com o divino devem ser reescritos (um-schreiben) para servirem para a experiência de devoção comunitária; 
- Imposição rígida da clausura, controlada por um confessor/diretor espiritual masculino que vem tomar residência no próprio convento das mulheres. Esse confessor residente será o porta-voz das monjas para o mundo exterior e o intermediário delas para os contatos com a hierarquia masculina da ordem dominicana. A palavra de Deus, daqui em diante, só poderá chegar às monjas pela voz desse intermediário masculino.

Monica Neidhardt mantém, no título da tese, o termo obediência (Gehorsam) para a interpretação de toda a reforma. Porém, no contexto violento da destruição das bases da vida monástica feminina e da imposição, às monjas, de nova ordem/regime que elas rejeitam, cindese, na verdade e de forma dramática, o que parece incindível. O termo obediência toma dois sentidos diferentes que são gender-specific. Mantém-se o seu sentido convencional para, aos monges que escolheram, viver conforme a regra dominicana, ao passo que, para as monjas, a obediência monástica é redefinida e forçada, transformando-se em submissão e servidão. Tratase de uma das estratégias linguísticas mais perversas - e eficazes - que utilizará, a partir dos Tempos Modernos, o patriarcado para silenciar as mulheres. Destroem-se as bases do matrimônio que fundava a comunidade feminina, por meio de uma estratégia ideológica e linguística e perversa: instalam-se duas formas de "obediência", mas preserva -se o termo tradicional cuja permanência cria a ilusão da continuidade e igualdade de todos, monges e monjas, perante a regra dita "única".

As correspondências, crônicas e discussões teológicas analisadas por Neidhardt mostram a resistência e as lutas das monjas do Sul da Alemanha para poder manter a sua autonomia e o direito de viver segundo as regras da sua própria cultura monástica intelectual, teológica e mística, a exemplo da monja teóloga Kunnigunde Hallerin que, no Sul da Alemanha do século XV, e ainda na tradição das monjas anglo-saxônicas, "ela transformava as ordenanças da Ordem dominicana em regras próprias, suportáveis por sua comunidade. Ela controlava um conhecimento (discursivo, teológico), atualizando e interpretando-o como teóloga perita" (NEIDHART, 2017, tradução minha) ${ }^{6}$.

\footnotetext{
${ }^{6}$ No original: "formte die Vorgaben des Ordens zu eigenen, für ihre Gemeinschaft tragbaren Regeln um! Wissen (diskursives, theologisches) wurde kontrolliert, aktualisiert und interpretiert durch sie als Expertin"
} 


\section{Did women have a Renaissance?}

\section{De dualidade a dualismo}

Chegamos ao final da Idade-Média, de mil anos durante os quais as relações entre os sexos estavam fundadas em uma complementaridade/dualidade pluriforme, múltipla, sempre questionada, sempre ambígua, sempre ameaçada, mas real, de um patrimônio à procura de potestas masculina, contrabalançado por um matrimônio fundamentado na auctoritas da abadessa e garantia da vida e bem-estar de toda a comunidade. As correspondências e outros documentos das monjas que viviam no limiar dos tempos modernos da Alemanha do Sul, reunidos por Stephanie Neidhardt, trazem o que se chama, em inglês, de eye-opener. De repente, eles revelam outra história da Idade Média, a saber: a história de mil anos de resistência, rebeldia e luta de muitos e variados Matrimônios locais e regionais, plurais contra um Patrimônio que se pretende suprarregional, único, superior e universal; uma luta que revela, ao mesmo tempo, a história da coexistência e do confronto permanente de duas visões do mundo e da vida.

De um lado, são mulheres com homens aliados, cuja visão e missão se concentram na Vida, na responsibilidade de todos os seres humanos pela Vida e na unidade cósmica de todos os seres vivos. Do outro lado, uma casta masculina de rezadores-pregadores e predadoresguerreiros, detentores de uma outra visão do mundo, de outro projeto histórico. Inspirada pelos pais fundadores da Igreja Católica, os apóstolos Pedro e Paulo, o objetivo dessa casta é o lento e progressivo silenciamento da autoridade e da visão do mundo da mulher, por meio da apropriação e extinção dos matrimônios locais e regionais pela imposição da potestas masculina como universal e todo-poderosa. Observada com as lentes da mulher, a Aliança políticoreligiosa instalada no mundo indo-europeu em 325 com o Concílio de Niceia efetuou, no decorrer dos mil anos chamados de Idade Média, a colonização interna do mundo indo-europeu, antes de passar, no século XV, à colonização/conquista do resto do mundo.

As monjas do Sul da Alemanha defenderam ainda, no século XV, com muita força, o seu mundo/matrimônio local e regional pluriforme contra as regras e leis universalizantes e internacionais, abstratas e impostas de fora, de cima e de longe, por uma casta político-religiosa masculina, cada vez mais hegemônica. Elas atuavam em um contexto cultural que aprendemos na nossa formação acadêmica a admirar como Renascimento e que constitui o momento em que se integrou, na casta político-religiosa, uma nova elite social: a dos eruditos/inteletuais humanistas que trazem uma nova visão do mundo, chamada de Humanismo. 


\section{De matrimônio a casamento}

Essa "modernidade / renascença" trouxe também, na Europa do século XV, a generalização do padrão único e exclusivo do casamento monogâmico, contra a variedade e pluriformidade dos “casamentos/uniões” tradicionais (LEMAIRE, 2012).

A última occorrência do termo francês matrimoine, no sentido original de "bens matrilineares", data de 1408. A partir do século XV, a palavra torna-se obsoleta e tomará em francês um sentido burlesco, estratégia discursiva muito frequente até hoje em dia para ridiculizar a voz feminina na cultura. Em francês, o novo tipo de casamento monogâmico recebe o nome de mariage. Em espagnol e italiano, é o termo de matrimônio que se tornará a palavra oficial para esse novo "casamento" e, em português, ele se generaliza como sinônimo. Nas tradições orais europeias, as alegres canções das mulheres medievais, "malmaridadas" com homem velho, violento e mal-cheiroso - gênero poético que cantava a felicidade e os prazeres vividos com o amante jovem, cheiroso e bonito - cedem o passo diante de um novo subgênero literário, a canção da malmaridada, cantada com os ritmos, as melodias e as estruturas versificatórias do gênero tradicional. São queixas de mulheres tristes e choronas, prisoneiras da casa e de uma enfiada de crianças famintas, vítimas de maridos irresponsáveis e violentos que se divertem fora da casa.

Nessa vida pública "moderna" do Sul da Alemanha, Kunigunde Hallerin e as outras monjas rebeldes e resistentes estão conscientes do que as esperam desde o ano 1310, quando é queimada, na França, a beguina-poeta mística Marguerite Porete (1250-1310): as fogueiras da Inquisição. Instituída pelos padres dominicanos, sob a autoridade dos papas de Roma e em aliança com as elites políticas locais, é ela que organiza e legitima como "vontade de Deus" um gigantesco massacre secular, cujo objetivo foi por fim ao matrimônio e - através desse feminicídio massivo de mulheres chamadas de bruxas - à dualidade pluriforme indo-europeia e pré-cristã que embasava e sustentava o sempre frágil e ameaçado equilíbrio dos dois mundos, o dos homens e o das mulheres.

\section{De colaboração a feminicídio}

Não, como já demonstrou Joan Kelly-Gadol (1977), as mulheres não tiveram uma Renascença! A Renascença - para as mulheres! - trouxe um horrível feminicídio: o massacre, durante mais de três séculos, de centenas de milhares de mulheres detentoras e guardiãs de uma 
visão da vida, do mundo, do divino, da natureza, da medicina própria dos matrimônios. As mulheres perderam o seu "mundo", que servia também como garde-fou (lit: parapeito/proteção contra louco) contra a violência e potestas masculinas. Até hoje, chamamos as mulheres massacradas de bruxas, sem conseguirmos desfazer-nos do imaginário convencional das miseráveis caricaturas de velhas feias, sujas, que voam à noite, sentadas em vassouras, para os seus delírios sexuais noturnos, praticados com o diabo; mito e caricatura que a Igreja católica inventou para justificar o seu crime hediondo contra a humanidade e a vida.

A violência intrínseca e a perversidade do patriarcado "moderno" começaram, já no século XV, a acometer o sistema linguístico medieval ainda potencialmente aberto e plural, para transformá-lo progressivamente no decorrer dos tempos modernos no sistema linguístico moderno ocidental, dicotômico, hierárquico, violento, fechado e gender-specific. Nele, inúmeras serão as palavras que, como a Gehorsam da Observanz dominicana, terão, para homens e mulheres, sentidos diferentes, serão gender-specific. Vejamos, por exemplo, a palavra-chave do feminicídio "bruxas", cuja história, na língua francesa é exemplar. Sorcier/sorcière em francês, strega em italiano, heks/hexe em holandês/alemão, witch em inglês, bruxa/bruja na Península Ibérica. A imensa variedade dos termos - locais, regionais-, além dos aqui citados, que existiam na Europa revela as suas raízes arcaicas pré-indo-europeias que estão embaraçando os linguístas-etimólogos que descobrem neles todos, invariavelmente, sentidos positivos, relacionados ao divino, ao sagrado, ao conhecimento, à adivinhação. Esses sentidos mantêm-se ainda nas línguas medievais, apesar das perseguições seculares pela Igreja, que já conseguiu lhes impor também muitas conotações negativas! Na língua francesa, é exatamente nos inícios dos tempos modernos que os termos medievais híbridos sorcier/sorcière, na sua dualidade ainda aberta, tornam-se gender-specific. Os seus sentidos, de ambíguos, transformam-se em um círculo hermenêutico fechado, dualista, instrumento ideológico do poder patriarcal. Um sorcier será, na França, a partir do século XVI, um homem com dons especiais (arte, inteligência, habilidade, perspicácia); uma sorcière uma mulher velha, feia e ruim.

\section{Mil anos de história medieval: variantes e invariantes}

A comparação da história milenar das monjas do Sul da Alemanha com a das monjas e dos conventos mistos duplos ao longo do Caminho de Santiago ilustra, em contextos religiosopolíticos radicalmente diferentes, a mesma evolução. São os mil anos da Reconquista (507- 
1429) da Península pela casta político-religiosa de guerreiros-reconquistadores e dignitários ecclesiásticos, sob a direcção do Papa de Roma. É a ordem beneditina/cistercience que conseguirá impor a sua regra monástica universal contra os monastérios de culto visigodo, hispano ou moçárabe, muitos deles dúplices mistos. Aqui, o matrimônio é outro: é o culto précristão da Mãe-Terra, das virgenes negras e brancas; são as mulheres sacerdotisas-predicadoras do Caminho de Fisterra que acolhem, alimentam, curam peregrinos e peregrinas, educandoos/as e ensinando-lhes tanto as verdades sagradas e os mistérios do culto da grande Deusa, quanto os milagres da sua representante terrestre, a virgen do lugar: Virgen del Manzano, Virgen de la Puente, Virgen del Paio, Virgen del Socorro, Virgen del Camino. Aqui, a luta é de concorrência aberta, feroz e secular entre o velho matrimônio e o novo patrimônio. Lembremos só dois marcos miliários: o primeiro caracterizado pela substituição, iniciada em 834, da Deusa-Mãe-Terra, pelo apóstolo Santiago - e do culto da Vida e da fecundidade pelo da Guerra; e o segundo, dado no decorrer dos séculos XII e XIII, com a substituição de todas as virgenes-dos-cem-mil nomes pela Virgem Maria, ao atribuir a Ela todos os milagres delas, dos quais a Virgem Maria se torna a "autora" exclusiva.

Focos, espaços geográficos e culturais, momentos históricos e interesses políticos, estratégias de silenciamento e erradicação. Trata-se de distintos aspectos, mas uma invariante sobressai-se com toda a pertinência: é a da "marcha" heroica e sagrada da civilização única e "supérior", dentro da qual inúmeros grandes e pequenos matrimônios locais, regionais antiquíssimos são confrontados à mesma casta masculina político-religiosa suprarregional, à mesma “colonização" violenta e cruel.

Lenta e progressivamente, no decorrer dos séculos medievais, mediante um processo de colonização interna do mundo indo-europeu, de centralização, sacralização e universalização do novo poder, fundado e legitimado como vontade divina e obra de Deus, o patrimôniopatriarcado impõe-se como único, verdadeiro e universal.

É essa noção e consciência de uma colonização interna que permite enxergar, nos interstícios dos relatos de guerras sempre justas e santas, de revoluções, renascenças e reformas, uma outra História. Essa História, paralela à História oficial, mostra que, a cada marco miliário, a cada grande evento histórico apresentado como civilizatório e legitimado como vontade divina, o patrimônio/potestas ganha terreno e território. E é nesse mesmo processo que o matrimônio-auctoritas - guardião e garantidor da posição social e dos direitos das mulheres terá o seu espaço de vida, de fala, de ação, de autoridade cada vez mais limitado. Tanto no Sul da Alemanha quanto no Norte da Península ibérica, a cada marco miliário heroico, a partir de 
mil anos de contestações, lutas e resistência feminina, assistimos à lenta e progressiva transformação/mutação das monjas viajantes, teólogas, pregadoras, sacerdotisas, educadoras e médicas em monjas clausuradas, submissas e silenciadas ${ }^{7}$.

\section{Divide et impera}

São as lentes do matrimônio e da sua história que, até hoje, só enxergamos fragmentada que permitem cercar, de repente, a outra invariante da história milenar do patriarcado: sua estratégia de "boa guerra" medieval - divide et impera - aplicada contra o matrimônio. Na arte guerreira medieval, ela consiste em fragilizar a força e a solidariedade do exército inimigo como grupo/coletivo, por meio de manobras "espertas" que isolam, desapegam, des-solidarizam, cercam inimigos individuais ou seções da sua infantaria. No caso do adversário-mulher, a estratégia serve para aproveitar a vulnerabilidade e a dependência das mulheres "individualizadas" - pelo casamento monogâmico, pelo ideal do amor cortês, pela clausura, pela dependência de um padre-confessor - para a propagação da ideologia da fraqueza do "sexo feminino" e da legitimação de medidas de restrição do espaço de ação e da mobilidade delas. Mutatis mutandis, é essa estratégia que os colonizadores vão levar para o Brasil colonial e que, até hoje em dia, é prática corrente nas políticas indigenistas dos governos successivos (SEGATO, 2012).

Em termos de História da Literatura, passamos definitivamente do capítulo das cantigas de amigo dialogadas - cantadas por grupos de mulheres, com os amores e bailadas de protagonistas, todas elas sempre belas, delgadas, louçanas, velidas, formosas (no plural), que cantam abertamente no espaço social da comunidade - para entrarmos no mundo do Amor (cortês) pela mais bela mulher (no singular) do mundo, superior a todas as outras, adorada, mas imobilizada em um pedestal, no silêncio e invisibilidade de um Amor exclusivo e espiritual, cultivado no espaço altamente privatizado do segredo. Ora, é esse ideal amoroso que a historiografia oficial das nossas literaturas nacionais celebra como o primeiro e verdadeiro ideal de amor ocidental (ROUGEMONT, 1939), cuja propagação, aos poucos, formatará a mente e o imaginário das mulheres, transformando a sua autoconfiança, independência e solidariedade em insegurança e dependência, levando-as a considerar toda e qualquer outra mulher como rival e concorrente potencial.

\footnotetext{
${ }^{7}$ Hoje em dia, escravas domésticas e sexuais da hierarquia masculina da Igreja católica, como revela o filme documentário intitulado Religieuses abusées, da televisão franco-alemã. Arte, que saiu em fevereiro 2018 e que a Igreja conseguiu logo proibir.
} 


\title{
Reinventar a história da Idade Média
}

\author{
Menina que tanto sabe \\ diga me aonde aprendeu \\ diga me aonde é que estava \\ quando a sua mãe nasceu. \\ (Quadra tradicional portuguesa)
}

\section{De precursoras a detentoras: mudar de lentes}

Geralmente, e dentro dos cânones da historiografia oficial, as mulheres, cujos nomes e obras sobreviveram ao processo da lenta e progressiva extinção da voz da mulher, são apresentadas e estudadas como mulheres excepcionais - mulheres-álibi -, inovadoras e precursoras. Quer dizer, como protagonistas heroicas e individuais da longa marcha do progresso da humanidade ocidental que, hoje em dia, enfim, permitiria a ascensão das mulheres. Essa ainda é a gaiola dourada da História única, superior e universal; é o espaço convencional do nosso pensamento bem formatado, domesticado, treinado para só olhar por meio das grades da gaiola, em vez de destruí-las para podermos pesquisar, questionar e desmascarar os seus fundamentos, estruturas, discursos e gênese, a sua "arqueologia".

A estratégia principal da reinvenção da historiografia terá que colocar como foco principal e central a história do matrimônio e das mulheres como detentoras e

\footnotetext{
agente coletivo de um projeto histórico, que se percebe como proveniente de um passado comum e construindo um futuro também comum, através de uma trama interna que não dispensa os conflitos, os antagonismos [...] mas que compartilha uma história. (SEGATO, 2012, p. 111).
}

É a consciência da existência secular e a continuidade desse "projeto histórico" que são essenciais para uma nova historiografia que tem de ser, contrariamente à História do patrimônio, um percurso de via dupla, ser ao mesmo tempo desaprendizagem e desconstrução da história patriarcal e redescoberta, resgate e re-invenção da história do mundo das mulheres como matrimônio.

Essa "via dupla" foi, como mostram as correspondências das monjas, também a da vida interna da comunidade monástica feminina, dividida entre a lealdade à missão de ajuda, cura, educação e edificação da comunidade local e regional, de um lado, e, de outro lado, o seu voto 
monástico de obediência à Regra do Papa, que as obrigava a contínuas adaptações, concessões e cada vez mais automutilações como estratégias de sobrevivência.

\section{Detentoras e educadoras: mudar de projeto histórico}

A consciência lúcida da dualidade original do mundo indo-europeu, da existência de dois "mundos" e "projetos históricos", cada um com a sua visão do mundo, os seus direitos, deveres e responsabilidades, está na base dos dois tipos de escritos femininos que as historiadoras das monjas alemãs distinguem. Desde as monjas anglo-saxônicas até Kunigunde Hallerin, no limiar dos tempos modernos, são, de um lado, os debates teológicos, abstratos e doutrinários em um pé de igualdade com a hierarquia masculina e, geralmente, redigidos em latim - o falar de fora, de cima e de longe. De outro lado, são os escritos - cada vez mais redigidos em línguas vernáculas! -, cujo objetivo é a edificação, educação e bem-estar da comunidade monástica das mulheres, dos homens aliados e das comunidades humanas e seres vivos em torno do monastério. Esses escritos não vêm de fora sob forma de leis, dogmas e penitências; eles estão baseados em um olhar de dentro, na experiência da vida, em uma ciênciaconsciência que dá conta dessa vida, está radicada nela, dialoga sobre ela e que é, como diria, hoje em dia, a escritora negra Conceição Evaristo, escrevivência.

Em um contexto em que o matrimônio vive sob a pressão permanente de um patrimônio invasor e autoritário, a educação/ensino das mulheres estava no centro das preocupações e atividades das monjas. Concorrentes do projeto patriarcal dominante, elas são testemunhas e defensoras, juntamente com muitos homens aliados, de um "projeto histórico" que se fundamenta em uma outra "ciência", em uma "ciência-consciência" da vida, do corpo, da sexualidade, da natureza, do divino, da relação/conexão entre corpo e mente, entre mente e emoção, da necessidade permanente de defender esses bens contra a violência e sede de poder masculinas. Os seus ideais não se baseiam em uma realidade construída com os egos sobredimensionados de heróis individuais, com guerra, conquista, morte, posse e poder, mas se resumem bem com a ajuda da palavra Minne, que é a palavra-chave das obras da poeta mística flamenga Hadewych de Antuérpia, beguina que viveu no século XIII. O substantivo Minne vem do verbo flamengo be-minnen e quer dizer "amar a". Essa minne que Hadewych ensina, além da pobreza e humildade, como Regra principal da vida da comunidade beguina, tem duas vertentes: o Amor incondicional ao Divino e a Compaixão incondicional dedicada a todos os seres vivos. 


\section{Conclusão inconclusa}

As histórias das monjas alemãs e ibéricas não são só de mulheres - nem de gender/gênero no sentido atual da palavra. O matrimônio teve sempre - e tem até hoje - inúmeros admiradores, amigos, praticantes, propagadores e defensores masculinos, aderentes do "seu projeto histórico".

Ao seguirmos o Caminho de Santiago, revivemos o longínquo passado de peregrinos e peregrinas do antigo Caminho, a sua devoção ardente da Deusa Mãe-Terra, das suas virgenes locais, o seu culto celebrado nos conventos mistos duplos. Redescobrimos, nesse Caminho, a vida dos monastérios duplos, tão parecidos com os da Alemanha do Sul, mulheres fundadoras de monastérios apoiadas por homens poderosos, maridos, familiares, reis. Lemos novos relatos de longas viagens que fizeram monges e monjas ibéricas para se encontrarem, se consultarem e discutirem questões teológicas; para trocarem riquíssimas correspondências, amizades e solidariedades. Assistimas a lutas comuns de mulheres teólogas e homens teólogos, daqueles homens que nunca se resignaram à interpretação unilateral, interesseira e falsificada dos ensinamentos do Cristo, propagada pela Igreja. E lembramo-nos dos numerosos patriarcas que, ao desafiarem a ordem patriarcal vigente, estimularam as suas filhas para estudar, educar, fundar monastérios.

Também encontramos a memória de homens que denunciavam aquela obsessão do pecado e das penitências, essas chantagens e abusos como fonte de renda e riqueza permanente do clero, ou reprovavam a aliança da sua hierarquia com os ricos da terra, ou ainda destestavam a concupiscencia ${ }^{8}$ que reinava nos conventos masculinos e no seio da casta político-religiosa. E pensamos na vida de tantos movimentos religiosos, perseguidos como seitas, tais como os Priscilianistas (séc. IV-V) ou os Cátaros (XII-XIII), que tentavam viver conforme os autênticos ensinamentos do Cristo, consignados nos evangelhos ditos apócrifos e excluídos do cânone estabelecido no final do século IV. Evocamos, comovidas, essas "seitas" cujos membros, homens e mulheres, viviam a sua fé em um pé de igualdade e, condenados à morte pelos "bons cristãos”, dirigiam-se, de mãos dadas e cantando hinos, às fogueiras da Inquisição.

Por isso, a nova História não pode ser uma história só de mulheres. Será a história também de seus aliados masculinos e de todos aqueles homens que tiveram a coragem de não se deixarem emascular, abrutir e intoxicar pelo modelo masculino vigente. Esses homens, cada

\footnotetext{
${ }^{8}$ No duplo sentido do termo: desejo imenso de bens e gozos materiais de um lado, de apetites sexuais exacerbados, de outro lado (Novo Dicionário Aurélio).
} 
vez mais conscientes da masculinidade tóxica e perversa do patriarcado ${ }^{9}$ - na sua versão específica ocidental - terão que fazer, como as mulheres, a sua "arqueologia" do saber mutilante e visceralmente violento da cultura moderna que solapa, hoje em dia, as bases da sociedade ocidental e a sua capacidade de sobrevivência. Eles terão que desconstruir, por sua vez, e como se faz nos estudos de gênero, a main-stream science toda poderosa, essa ciência sem consciência que "é ruína da alma", como já anunciou o pensador-escritor francês François Rabelais, no limiar dos Tempos ditos Modernos. Ruína da alma e da Vida que, nesse limiar do século XXI, se desvela aos olhos de uma humanidade desemparada em uma sociedade que se tornou intrinsicamente violenta e mortífera.

\section{Referências}

A.A.A.S. "Medieval women's early involvement in manuscript production suggested by lapis lazuli identification in dental calculus". In: Science Advances, American Association for the Advancement of Science v. 5, n. 1, janeiro, 2019.

ARAGON, Louis. La Nuit de Moscou. sd. sl. Au large - à Marguerite Porete et quelques autres.

BEACH, Alison. Women as Scribes. Book Production and Monastic Reform in 12th- Century Bavaria, Cambridge Studies in Paleography and Codicology, 10, Cambridge University Press, 2004.

CYRUS, Cynthia J. The Scribes for Women's Convents in Medieval Germany, Toronto, University of Toronto Press, Toronto, 2009.

FERREIRA, Manuel Pedro. Tradicionalismo e inovação musical na cantiga paralelística. In: GUERRA, Alexandre, FREIXEDO, Xosé Bieito. The vindel parchment and Martin Codax / O pergaminho Vindel e Martin Codax. Amsterdam/Philadelphia: John Benjamins Publisching Company, 2018, p.239-255.

FOUCAULT, Michel. "Qu' est-ce qu' un auteur ? " Conférence au Collège de France, 1969. Trad. "What is an Author?". In : NESTER, W.R., Modernity and its Discontents. New York, Palgrave, $2010: 298-314$.

FOUCAULT, Michel. L’ archéologie du savoir. Paris, Gallimard, 1969.

GUERRA, A. e FREIXEDO, X.B., The Vindel Parchment and Martin Codax/O Pergamiño Vindel e Martin Codax, John Benjamins, Amsterdam/Philadelphia, 2018.

KELLY-GADOL, Joan Did "Women Have a Renaissance ?”. In: BRIDENTHAL, Renate e /Claudia KOONZ, Women in European History, Houghton Mifflin, Boston, 1977: 137-164.

\footnotetext{
${ }^{9}$ Como faz o movimento internacional e intercontinental Men EngageAlliance, que traz uma reflexão crítica fundamental sobre a violência masculina no mundo e elabora estratégias de uma nova educação e re-educação dos homens, baseada desde os primeiros anos de vida dos meninos sobre a formação de outras maneiras de lidar com as pulsões de uma violência que a sociedade atual só ativa, estimula e faz aumentar.
} 
LEMAIRE, Ria. "Cantigas, casamentos, contextos"”. In: FREIXEDO, Bieito Arias, Sementar para os que veñan - Homenaxe a Camiño Noia, Universidade de Vigo, 2012, 167-184.

LEMAIRE, Ria. "Patrimônio e Matrimônio I: proposta para uma nova historiografia da cultura ocidental”, In: Educar em Revista n. 70, jul-ago 2018, p. 17-33.

LEMAIRE, Ria. "Patrimônio e Matrimônio II: Repensar a historiografia das literaturas nacionais", In: Revista de Estudos Linguísticos e Literários no. 59, UFBA, Salvador, janeiro-junho 2018, p. 54-72.

LIFSCHITZ, Felice. Religious Women in Early Carolingian Francia- a Study of Manuscript Transmission and Monastic Culture, Bronx, Fordham University Press, 2014.

MICHAELIS DE VASCONCELlOS, Carolina. O Cancioneiro da Ajuda, 2 vols, Halle, Niemeyer, 1904, vol. II, cap. 8-9.

NEIDHARDT, Stefanie, Autonomie im Gehorsam. Die dominikanische Observanz in Selbstzeugnissen geistlicher Frauen des Spätmittelalters, In: Vita Regularis, Abh. 70, Münster/Hamburg/Berlin/London, 2017.

RESENDE DE OLIVEIRA, A. Depois do Espetáculo Trovadoresco. A estrutura dos cancioneiros peninsulares e as recolhas dos séculos XIII e XIV, Lisboa, Ed. Colibri, 1994.

ROMERALO, Antonio Sánchez, EI Villancico - estudios sobre la lírica popular en los siglos XV y XVI, Ed. Gredos, Madrid, 1969, p. 16-23.

ROUGEMONT, Denis de. L'amour et l'Occident, Paris, 1939.

SEGATO, Rita. "Gênero e colonialidade: em busca de chaves de leitura e de um vocabulário estratégico descolonial”, In: e-cadernos CES, 18, 2012: 106-130.

VANCE, E. "Signs of the City: Medieval Poetry as Detour". In: New Literary History, 4, 1972: 557571.

WHITE, Hayden. Metahistory: The Historical Imagination in Nineteenth-Century Europe. Baltimore: John Hopkins, 1973.

ZUMTHOR, Paul. Parler du Moyen-Age. Paris, Minuit, 1980.

ZUMTHOR, Paul. Introduction à la poésie orale, Paris, Seuil, 1983.

ZUMTHOR, Paul. De la “littérature“ médiévale. Paris, Seuil, 1987.

Recebido em: 18/08/2020

Aceito para publicação em: 23/11/2020 